PRÁVNE ROZPRAVY ON-SCREEN III. - Sekcia súkromného práva

online vedecká konferencia - 7. máj 2021

\title{
MATERSKÁ DOVOLENKA
}

\section{MATERNITY LEAVE}

\section{Linda Ďurinová ${ }^{1}$}

https://doi.org/10.24040/pros.07.05.2021.ssp.83-90

\begin{abstract}
Abstrakt
Ciel’om článku je poskytnút' čitatel'ovi prehl’ad v špecifikách nastavenia materskej dovolenky v právnom poriadku Slovenskej republiky. Vyplácanie materskej dovolenky nie je automatické, hovoríme o dávke vyplácanej Sociálnou poistovňou. Na vyplácanie materského musí každá osoba splnit’ stanovené podmienky, ktorým sa v článku venujeme. Článok je zameraný na ženu žiadajúcu materské, ktorá je v trvalom pracovnom pomere, príp. vochrannej dobe.
\end{abstract}

\section{Kl’účové slová}

Materská dovolenka, pracovný pomer, ochranná doba, matka, zamestnanec

\begin{abstract}
The aim of the article is provide to reader specific overwiev of matenity leave in legal order of Slovak Republic. Maternity leave is not automatic payment, it is benefit paid by Social Insurance of Slovak Republic. The payment of the maternity allowance is conditioned by the fulfillment of the set conditions, which we deal with in the article. The article is aimed at a woman requesting maternity leave who is in a permanent employment relationship, or during the protection period.
\end{abstract}

\section{Keywords}

Maternity leave, employment relationship, period of protection, mother, employee

\section{Úvod}

Materské je jedna z dávok vyplácaných zo systému nemocenského poistenia. Materské teda vypláca Sociálna poist’ovňa a nie je vyplácané automaticky. Pre vyplácanie materského musí matka alebo otec diet’at’a splnit' určité podmienky, ktoré sú uvedené v zákone o sociálnom poistení.

\footnotetext{
${ }^{1}$ PaedDr. Bc. Linda Duurinová, študent externého štúdia Právnickej fakulty Univerzity Mateja Bela v Banskej Bystrici
} 


\section{PRÁVNE ROZPRAVY ON-SCREEN III. - Sekcia súkromného práva}

online vedecká konferencia - 7. máj 2021

V článku sa venujeme materskému vyplácanému matke, ktorej plynie nárok na vyplácanie z trvalého pracovného pomeru. Nárok na vyplácanie môže samozrejme plynút’ aj otcovi, matke z dobrovol'ného nemocenského poistenia, atd'. Možností je skutočne viacero a pre obsiahlost' témy spracujeme len materské vyplácané matke, ktorej nárok plynie z trvalého pracovného pomeru, resp. je matka v ochrannej lehote a na základe toho má nárok na materské.

Pre situáciu, ktorej sa v článku venujeme nie sú pre rok 2021 žiadne legislatívne zmeny. Samozrejmost’ou je však medziročná zmena maximálnej výšky materského, ktorá sa vypočítava ako 75\% denného vymeriavacieho základu z dvojnásobku priemernej výšky mzdy v roku 2020. V roku 2021 teda hovoríme o maximálnom materskom 1615,60€ pri 30dňovom mesiaci a 1669,50€ pri 31- dňovom mesiaci. Maximálne materské teda získa poistenkyňa, ktorej príjem dosahoval $2184 €$ mesačne a viac.

V článku sa venujeme všeobecne materskému, výpočtu výšky, ktoré má matka vyplácané a počtu týždňov, počas, ktorých je materské vyplácané.

Nakol'ko ide dnes o pomerne diskutovanú tému, ked’že v čase pandémie mnoho zamestnávatel'ov prerušuje pracovné zmluvy je potrebné hovorit' o podmienkach vyplácania materského, aby sa budúce mamičky vedeli zorientovat' v problematike.

\section{Jadro}

Materské je tak ako sme uviedli nemocenská dávka vyplácaná Sociálnou poist’ovňou. Nárok na vyplácanie plynie zo zákona o sociálnom poistení. Materské je vyplácané po dobu 34, 37 alebo 43 týždňov.

- 34 týždňov pri pôrode jedného diet'at'a;

- 37 týždňov pri pôrode jedného diet’at’a osamelou matkou, avšak túto osamelost' musí preukázat' po celú dobu poberania materského;

- 43 týždňov pokial' ide o narodenie dvojičiek, trojičiek,... vtedy hovoríme o viacpočetnom pôrode. 


\section{PRÁVNE ROZPRAVY ON-SCREEN III. - Sekcia súkromného práva}

online vedecká konferencia - 7. máj 2021

Materské je vyplácané vždy do konca mesiaca za predchádzajúci mesiac na účet v banke, ktorý matka uviedla priamo $\mathrm{v}$ žiadosti, resp. v hotovosti, pokial' tak bolo $\mathrm{v}$ žiadosti o poskytnutie materského uvedené.

Žiadost' nie je vol'ne dostupná v Sociálnej poist'ovni, budúca matka pred nástupom na materskú dovolenku dostane vypísané tlačivo u svojho gynekológa. Lekár vypíše tlačivo, kde vyznačí aj termín nástupu na materskú dovolenku. Budúca matka však do tlačiva dopíše údaje ako: číslo účtu kam chce, aby jej bolo materské vyplácané, nemocenské poistenie, z ktorého si materské uplatňuje. Môže však nastat’ aj prípad, kedy je nemocenských poistení viacero a pre každé si budúca mamička vyžiada samostatné tlačivo. Tlačivo je potrebné doručit' zamestnávatel'ovi, ktorý odvádzal nemocenské poistenie, z ktorého sa nárok na materské uplatňuje. Daný zamestnávatel' následne tlačivo doplní, kde uvedie dátum nástupu na materskú dovolenku a tlačivo doručí príslušnej Sociálnej poist’ovni.

Sociálna poist'ovňa tlačivo spracuje a následne do 60 dní zašle poistenkyni rozhodnutie. V prípade, ak Sociálna poist'ovňa z akéhokol’vek dôvodu do 60 dní nerozhodne, musí o tom upovedomit' poistenkyňu a tak sa lehota na rozhodnutie predíži o d'alších 60 dní. V praxi sa často stretávame s prípadmi, kedy je materské poistenkyni zaslané a rozhodnutie dostane až následne.

V rozhodnutí je uvedené, či je alebo nie je priznané materské. Ďalším bodom rozhodnutia je, z ktorého nemocenského poistenia bude materské plynút', ktorý deň je pre vyplácanie prvým a v akej výške je materské priznané. Výška je uvedená za jeden deň.

Pokial' poistenkyňa nesúhlasí s rozhodnutím je možné sa odvolat' do 30 dní od doručenia rozhodnutia, v odvolaní je dôležité uviest' rozhodujúce skutočnosti na základe, ktorých poistenkyňa žiada o prehodnotenie rozhodnutia.

Materské sa vypláca 6 alebo 8 týždňov pred plánovaným termínom pôrodu. Štandardne ide o nástup na materskú dovolenku 6 týždňov pred plánovaným termínom pôrodu. Nástup na materskú dovolenku 8 týždňov pred termínom pôrodu je v prípade zdravotných komplikácií budúcej mamičky. V prípade, že ide o budúcu mamičku, ktorá bude v ochrannej dobe, nástup na materskú je 8 týždňov pre určeným termínom pôrodu.

Rozhodujúce obdobie je obdobie, z ktorého sa výška materského vypočítava. Pred zadefinovaním rozhodujúceho obdobia je potrebné uviest', že prvou základnou podmienkou je mat’ nemocenské poistenie v dížke minimálne 270 dní počas posledných dvoch rokov pred dňom pôrodu (skutočný deň pôrodu, nie ten lekárom určený). 


\section{PRÁVNE ROZPRAVY ON-SCREEN III. - Sekcia súkromného práva}

online vedecká konferencia - 7. máj 2021

Ochranná lehota je obdobie počas, ktorého budúca mamička nemá nemocenské poistenie, ale zároveň bude mat' nárok na materské. V takomto období môže byt' žena 8 mesiacov pred určeným termínom pôrodu.

Ako príklad uvedieme budúcu mamičku s trvalým pracovným pomerom uzatvoreným na dobu určitú. Dobru určitú sme zvolili nakol'ko sa v praxi čoraz častejšie u zamestnávatel'ov vyskytuje využívanie doby určitej v maximálnej možnej miere. Zamestnancov teda prijímajú na 1r dobu určitú, ktorú im následne predlžujú opät’ na 1r doby určitej a až následne sa pristupuje k predlžovaniu na dobu neurčitú.

Dôležité je upozornit' aj na skutočnost', že zamestnankyňa je povinná svoje tehotenstvo oznámit' zamestnávatel'ovi a to písomne. Tehotná žena je chránená Zákonníkom práce, z ktorého vyplýva, že nemôže napr. dostat' výpoved', musí byt' preradená na pracovnú pozíciu, ktorá zodpovedá jej zdravotnému stavu - pokial' by mala napr. fyzicky náročnú prácu. Zamestnávatel’ovi sa štandardne oznamuje tehotenstvo samotné, predpokladaný termín pôrodu a nástupu na materskú dovolenku.

Tehotná žena sa dostáva aj do akejsi ochrannej lehoty v zamestnaní, počas ktorej nie je možné, aby dostala výpoved' zo strany zamestnávatel'a. Na rôznych fórach a blogoch sa stretávame s tvrdením, že tehotná žena dostala výpoved'. Dané tvrdenia sa však nezakladajú na pravdivých informáciách ked’že takéto riešenie zo strany zamestnávatel’a nie je možné. Je však možné, že sa pracovný pomer ukončí dohodou o ukončení pracovného pomeru, výpoved'ou zo strany zamestnanca a ukončením doby určitej - ide o nepredíženie pracovnej zmluvy bez udania dôvodu (považujeme za výhodu na strane zamestnávatel'a). Pri ukončení pracovného pomeru výpoved'ou zo strany zamestnanca a dohodou o ukončení pracovného pomeru môžeme teda povedat', že samotný zamestnanec, v našom prípade tehotná zamestnankyňa, musí s ukončením pracovného pomeru súhlasit’. Bez jej súhlasu ukončenie pracovného pomeru nie je možné.

Ďalším bodom, ktorému je dôležité venovat’ sa a vyplýva zo Zákonníka práce je, že zamestnávatel' je povinný poskytnút' tol'ko dní pre návštevu lekára tehotnej zamestnankyni kol'ko je potrebné. Nakol'ko je v tehotenstve potrebné častejšie navštevovat' lekára za účelom pravidelných kontrol, zamestnávatel' ich tehotnej zamestnankyni musí umožnit'. Umožní ich počtom dní pre návštevu lekára, kedy v tomto prípade sa môže prekročit' aj hranica 7 dní, ktorá plynie zo zákona. 


\section{PRÁVNE ROZPRAVY ON-SCREEN III. - Sekcia súkromného práva}

online vedecká konferencia - 7. máj 2021

Pokial' má teda budúca matka zamestnanie a s daným zamestnávatel’om ukončí pracovný pomer maximálne $8 \mathrm{~m}$ pred skutočným termínom pôrodu má nárok na materské za predpokladu:

- mala nemocenské poistenie minimálne 270 dní za posledné dva roky pred skutočným termínom pôrodu;

- do 270 dní nemocenského poistenia sa započítavajú aj dni nemocenského poistenia, za ktoré sa nemocenské poistenie neplatí - dni na materskej dovolenke, PN, 1-10 deň OČR.

Rozhodujúce obdobie pre výpočet materského pre budúcu matku (v ochrannej dobe) je v roku 2021, rok 2020, za ktorý mala platené nemocenské poistenie a materské vypočíta sa za dni, počas ktorých bolo platené nemocenské poistenie.

Druhým prípadom, ktorému sa v predloženom článku venujeme je budúca matka, ktorá má aktuálne pretrvávajúce nemocenské poistenie. V tomto prípade rozlišujeme niekol'ko možností:

- pracovný pomer vznikol v roku 2021 kedy je aj nástup na materskú dovolenku;

- pracovný pomer vznikol v roku 2020 a nemocenské poistenie je zaplatené za minimálne 90 dní;

- pracovný pomer vznikol pred 1.1.2020 a trvá nepretržite.

Jednotlivé typy výpočtu materského uvedieme na príkladoch pre jednoduchšie vysvetlenie.

\section{Pracovný pomer vznikol v roku 2021}

*predpoklad v uvedenom prípade je, že budúca matka žiadajúca materské má 270 dní nemocenského poistenia a teda $\mathrm{k}$ tejto skutočnosti sa nebude vracat'. Ide totiž o jednu zo základných podmienok pre priznanie materského, ktorej sme sa venovali vyššie v článku.

Našu budúcu mamičku pomenujme Alenka. Alenka uzatvorila pracovný pomer u nového zamestnávatel'a 1.1.2021.V roku 2020 má celý rok odpracovaný u predchádzajúceho zamestnávatel’a. Predpokladaný termín pôrodu má 25.5.2021.

1. Pani Alenka bude na materskú dovolenku nastupovat' 6 týždňov pred určeným termínom pôrodu, nakol'ko v danom termíne bude mat' splnených 90 dní a viac platenia nemocenského poistenia u nového zamestnávatel'a, materské sa jej bude 


\section{PRÁVNE ROZPRAVY ON-SCREEN III. - Sekcia súkromného práva}

online vedecká konferencia - 7. máj 2021

počítat' práve z toho príjmu. Rátame však s tým, že pani Alenka počas tohto obdobia nebola PN, OČR, prípadne na neplatenom vol'ne.

Pokial' by pani Alenka u nového zamestnávatel'a bola napr. PN z dôvodu rizikového tehotenstva, 90 dní platenia nemocenského poistenia by nesplnila a materské by sa jej teda rátalo z vymeriavacieho základu v roku 2020.

2. Pani Alenka bude na materskú dovolenku nastupovat' 8 týždňov pred určeným termínom pôrodu. Nakol'ko v roku 2021 nebude mat' u aktuálneho zamestnávatel'a splnených 90 dní zaplatené nemocenské poistenie. Vymeriavací základ sa teda nebude počítat' zo zamestnania v roku 2021, ale z roku 2020 kedy mala pani Alenka pracovný pomer u predchádzajúceho zamestnávatel'a.

V praxi sa stretneme aj s prípadmi kedy skutočne môžeme hovorit’ o „nastavenom“ príjme. O nastavenom príjme hovoríme vtedy ked’ má budúca matka napr. zamestnávatel’a s príjmom 900eur. Po otehotnení sa však zamestná u nového zamestnávatel'a s príjmom 2500eur, kde sa jej budú platit' odvody po dobu 90 dní. Materské by sa jej teda malo počítat' práve z tohto príjmu. Sociálna poist'ovňa však v takýchto prípadoch často preskúmava reálnost' zamestnania. Preverenie reálnosti sa vykonáva návštevou priamo u zamestnávatel’a a zist'ovaním, či daná zamestnankyňa reálne pracovala, prebieha komunikácia s kolegami a pod. Takýto proces nastáva v prípadoch kedy je nový príjem výrazne vy̌šsí ako bol pôvodný, nemocenské poistenie zaplatené len za „nutný““ počet dní.

Nový pracovný pomer je vo všeobecnosti chápaný ako pracovný pomer uzatvorený s novým zamestnávatel'om. Aj tu sa však nájde jedna výnimka. Nový pracovný pomer je možné uzatvorit' aj so zamestnávatel'om, u ktorého pracovný pomer zanikol napr. 1.3.2021 a nový pracovný pomer sa uzatvorí 2.3.2021. Z pohl'adu Sociálnej poist'ovne pri výpočte materského však o nový pracovný pomer nejde a výpočet bude prebiehat' tak, akoby predchádzajúca zmluva nezanikla, ale pokračovala. Ako nový pracovný pomer by to Sociálna poist'ovňa posudzovala len v prípade, že medzi jednotlivými pracovnými pomermi bude niekol'ko dní až týždňov časové preklenutie. 


\section{PRÁVNE ROZPRAVY ON-SCREEN III. - Sekcia súkromného práva}

online vedecká konferencia - 7. máj 2021

\section{Pracovný pomer vznikol v roku 2020 a nemocenské poistenie je zaplatené za minimálne 90 dní}

Môže nastat' situácia, kedy sa budúca mamička zamestná a po pár mesiacoch zistí, že čaká bábätko. Modelovým príkladom je napr. pani Alenka uzatvorila pracovný pomer 1.3.2020, termín pôrodu má 24.2.2021. Od 1.3.2020 do 15.11.2020 pani Alenka pracovala nepretržite, v tomto čase nebola PN, OČR a ani na neplatenom vol’ne. Od 16.11.2020 však pre rizikové tehotenstvo nastúpila na $\mathrm{PN}, \mathrm{z}$ ktorej pôjde následne na materskú dovolenku. Nakol'ko je v tomto prípade splnená podmienka 90 dní zaplateného nemocenského poistenia a zároveň aj splnená podmienka 270 dní nemocenského poistenia, materské priznané bude.

Rozhodujúcim obdobím pre výpočet bude denný vymeriavací základ za obdobie 1.3.2020 až 15.11.2020 - štandardne do konca mesiaca predchádzajúceho mesiacu, kedy je nástup na materskú dovolenku. V našom prípade však po 16.11. 2020 bola čerpaná PN a toto obdobie sa do DVZ neráta.

\section{Pracovný pomer vznikol pred 1.1 .2020 a trvá nepretržite}

Pokial' pracovný pomer vznikol pred 1.1.2020 a trval teda počas celého roka 2020 a pokračuje až do nástupu na materskú dovolenku, ktorá začne v roku 2021.

Prípad tohto typu môžeme považovat' za najjednoduchší, ked’že v tomto prípade sa bude denný vymeriavací základ počítat’ z príjmu v roku 2020. To znamená, že pokial' mala budúca mamička napríklad ročné odmeny, 13. plat, Vianočný príspevok a pod. celkový príjem je vyšší ako základný plat a materské sa ráta z celkového príjmu.

\section{Záver}

V článku sme uviedli špecifiká materského ako jedného typu nemocenského poistenia. Nakol'ko materské nie je automaticky schválené a každý žiadatel' musí splnit' isté základné podmienky, medzi ktoré patrí napríklad 270 dní nemocenského poistenia za posledné dva roky pred nástupom na materskú dovolenku. Druhou jednou zo základných podmienok je mat’ 


\section{PRÁVNE ROZPRAVY ON-SCREEN III. - Sekcia súkromného práva}

online vedecká konferencia - 7. máj 2021

minimálne 90 dní zaplateného nemocenského poistenia u zamestnávatel’a, z ktorého príjmu sa má počítat' materské.

Téma materského je dnes aktuálna nakol'ko sa nachádzame v dobe, kedy je pomerne časté menenie práce, nástupy k novým zamestnávatel’om, pracovné zmluvy na dobu určitú, prerušené nemocenské poistenia a podobne. Je preto vel'mi dôležité, aby aj v čase ked' žena zistí, že sa stane mamičkou, upovedomila zamestnávatel’a a vedela sa aspoň sčasti zorientovat' vo výpočtoch materského.

V predloženom článku sme poskytli prehl'ad o výpočte materského a dôležitých náležitostiach v prípade, že budúca mamička má trvajúci pracovný pomer, alebo ide o čas kedy hovoríme o ochrannej dobe.

Pre d'alšie rozpracovanie témy je možné spracovat' všetky možnosti, či by už išlo o príjem SZČO, dobrovol’né nemocenské poistenie, ret’azový pôrod atd'.

\section{ZOZNAM BIBLIOGRAFICKÝCH ODKAZOV}

\section{Monografie a učebnice:}

MIHÁL J. Materská 2020. Bratislava: RELIA, 2019. 204 s. ISBN 978-80-999500-1-7

MIHÁL J. Materská 2021. Bratislava: RELIA, 2019. 242 s. ISBN 978-80999500-5-5

\section{Internetové zdroje}

Materské . [online]. 2021. cit. [2021-04-28].

Dostupné na internete: https://www.socpoist.sk/definicia---ucel-davky-/1293s\#01

ČERNEGOVÁ A.: Maximálne materské v roku 202. In: www.podnikajte.sk [online], cit. [2021-04-25].

Dostupné na internete: https://www.podnikajte.sk/socialne-a-zdravotne-odvody/maximalnematerske-2021

Obsah článku podlieha licencii Creative Commons Attribution 4.0 International Licence CC BY (Linda Ďurinová). 